Research Article

\title{
Organizational Setup for Solid Waste Management Record Keeping
}

\author{
Nazish Huma Khan ${ }^{1 *}$, Mohammad Nafees ${ }^{2}$, Tooba Saeed ${ }^{3}$, Khaliq Ur Rahman ${ }^{4}$ and Adila Bashir ${ }^{2}$ \\ ${ }^{1}$ Department of Environmental Sciences, University of Swabi, Anbar, Khyber Pakbtunkbwa, Pakistan; ${ }^{2}$ Department of \\ Environmental Sciences University of Peshawar Khyber Pakbtunkhwa, Pakistan; ${ }^{3}$ National Centre of Excellence in Physical \\ Chemistry, University of Peshawar Khyber Pakhtunkbwa, Pakistan; ${ }^{4}$ Department of chemistry, University of Swabi, Anbar, \\ Khyber Pakbtunkbwa, Pakistan.
}

Abstract: In most parts of the world, particularly developing countries, there is no practice of keeping proper
records of the handling, treatment and disposal of urban and industrial solid wastes. For this reason, there are
difficulties in planning solid waste management. In this context, this study aims to determine the organization's
role in record keeping and solid waste management in the Hayatabad Industrial Zone, Peshawar. To this end,
a questionnaire survey was carried out among 105 industries and relevant government departments were
interviewed. The solid waste generation rate for the operating industries was $125,481 \mathrm{~kg} /$ day. Only $33 \%$
of the waste generated is reused, and $26 \%$ is sold to the community at low cost. About $41 \%$ solid waste is
thrown away as waste. Fifty percent of discarded waste (41\%) is properly collected and disposed of. These
wastes include wood (27\%), paper (20\%), glass/ceramics (16\%), metals (16\%), plastics (11\%), rubber (6\%),
and sand/stone (5\%). The waste management questionnaire survey showed poor performance in collection
(67.5\%), treatment (82.5\%) and recycling (42.5\%). This study proposes that there is no separate organizational
set up to separately treat industrial and municipal waste. As a result, it is difficult to manage the recovery of
industrial solid waste. Therefore, it is recommended that industrial wastes be handled properly with good
resource recovery.
Received: August 26, 2020; Accepted: June 23, 2021; Published: June 30, 2021
*Correspondence: Nazish Huma Khan, Department of Environmental Sciences, University of Swabi, Anbar, Khyber Pakhtunkhwa, Pakistan;
Email: humakhan@uoswabi.edu.pk
Citation: Khan, N.H., M. Nafees, T. Saeed, K.U. Rahman and A. Bashir. 2021. Organizational setup for solid waste management record keeping.
Journal of Engineering and Applied Sciences, $40(1): 60-68$.
DOI: https://dx.doi.org/10.17582/journal.jeas/40.1.60.68
Keywords: Solid waste, Industrial waste, Municipal waste, Management, Reuse, Control, Waste collection, Waste handling

\section{Introduction}

$\mathrm{T}$ he industrial sector is important for the economic development of a country. It offers different products and job employment to people (Kanchana et al., 2014; Ewijk et al., 2018). But on the other hand, it poses several environmental problems such as industries that generate waste and their treatment is a big problem (Homan et al., 2014). Generally, industries generate two types of waste, hazardous and non-hazardous (Haupt and Zschokke, 2017).
Hazardous waste includes chemicals, paints, metals ( $\mathrm{Pd}, \mathrm{Cd}, \mathrm{Cr}, \mathrm{Ni}, \mathrm{Cu}$, etc.) which are difficult to reuse or recycle in a conventional solid waste management system. Non-hazardous waste includes recyclable waste such as plastic, paper, metals and wood waste that can be recovered by conventional practices (Bhat et al., 2018).

As there is a continuous increase in both types of waste and their proper treatment and disposal is a big problem (Mahar et al., 2007). In the past, industries 
lacked technology and dumped waste into the surrounding area without any treatment (Arushanyan et al., 2017). Now, with the introduction of clean technologies, it is possible to treat industrial waste and maintain an environmentally friendly industry (Ljunggren et al., 2016).

In developing countries, the current solid waste management system is still inefficient. In Pakistan, there is no separate system for municipal and industrial solid waste management (Mahar et al., 2007; Nisar et al., 2008). Industrial waste is generally treated as common waste and is mixed with municipal waste. The total solid waste generated in Pakistan was calculated to be 70,715 tonnes/ day, including industrial solid waste. In total, around $51-69 \%$ of solid waste is collected daily in Pakistan. While uncollected waste is burned in the open or illegally dumped (Shah, 2014).

Due to the lack of separate treatment facilities, landfills and recycling systems, the negative impacts of solid waste are intensified with an unsanitary environment (Ljunggren et al., 2016). This mismanagement of solid waste is a regular source of environmental pollution with harmful effects on humans (Fan et al., 2017).

To know the management of industrial solid waste, this study was carried out by identifying an industrial zone (Hayatabad Industrial Estate, Peshawar) located in the residential zone. There were 242 functional industries. Solid waste from industries is collected and mixed with municipal waste to be landfilled. This study considered the solid waste production by industries and its organizational set-up for good management.

\section{Materials and Methods}

The methodologies adopted to achieve the objectives of the study are based on the collection of primary and secondary data. Secondary data was collected from the offices of the Sarhad Development Authority (SDA) and the Peshawar Development Authority (PDA). For the collection of primary data, survey methods were applied such as field visits and questionnaire surveys.

Reconnaissance survey was carried out to know about the present industrial set-up. For this, 10 field visits were paid to the estate. As a result of the reconnaissance survey of Hayatabad industrial estate, it was found that the industries can be divided into 20 different groups. Out of 20 groups, 19 were classified as major industries while the rest were small scale.

\section{Visits to Sarbad development authority office (SDA)}

To collect preliminary information and secondary data related to Hayatabad industrial estate (HIE), the office of Sarhad Development Authority (SDA) was visited. The following information were collected as;

- Total number of industries

- Present status of operating and closed industries

To find out the quantity of industrial solid waste, a questionnaire survey was carried out among 95 industries. In the response, 80 questionnaires were received which was $85 \%$ of the total distributed questionnaires (Figure 1). An attempt was made to select a representative sample for the questionnaire survey (Table 1). The number of industries varies from 1 to 5 , all industries (100\%) were visited. The number ranged from 6 to $15,50 \%$ were randomly selected for the survey, while numbers above 15, 25\% industries were selected (Table 1).

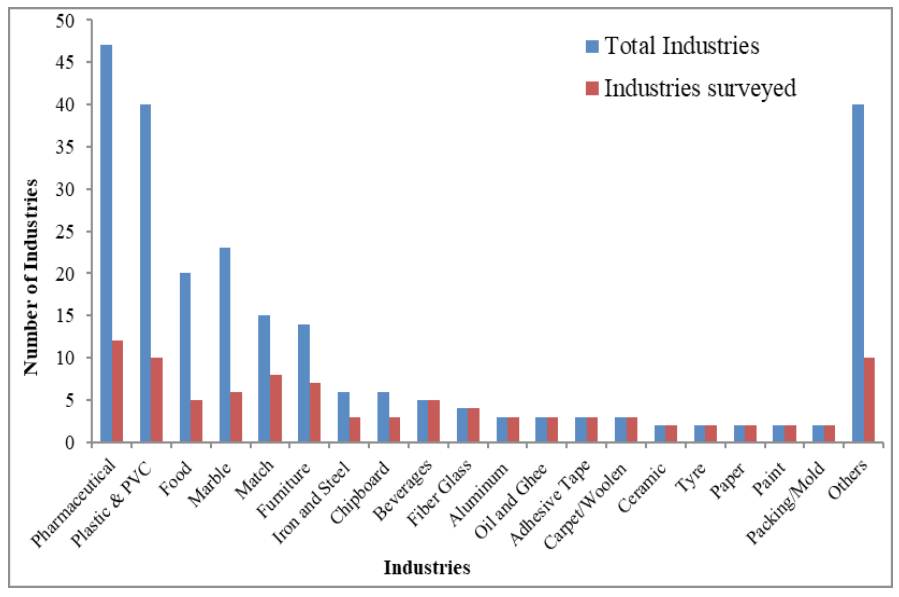

Figure 1: Industries surveyed during field visits.

Table 1: Sampling criteria.

\begin{tabular}{lll}
\hline S. No. & Number of industries & Percent sample (\%) \\
\hline 1 & $1-5$ & 100 \\
2 & $6-15$ & 50 \\
3 & $15-$ above & 25 \\
\hline
\end{tabular}

Another questionnaire was designed to collect data from Peshawar Development Authority (PDA)

PDA is an administrative department, responsible for solid waste collection and disposal. The office of PDA was visited and data was collected regarding industrial solid waste quantity, its collection and disposal. 
Waste management inside industries

To know about the waste handling and utilization inside the industry, a questionnaire was designed and pre-tested among industries.

\section{Solid waste disposal}

To know about the quantity and nature of industrial waste, the dumpsite was monitored for a period of 6 months. Total of 12 samples were collected @ two samples per month. A sample of a specific quantity $(300 \mathrm{Kg}$ ) was quantified at the dumping site.

\section{Solid waste composition}

To find the composition, samples were categorized for recyclable and non-recyclable waste. Different items of solid waste were identified and separated in labeled plastic bags. The waste items were in dry form such as paper, cardboard, wood, plastics, iron scrap, rubber, glass and ceramics, sand, stones etc. The weight of each item was measured using a digital scale. The quantity of each item was expressed in percentage (Table 2). Moreover, 30 scrap collection shops (kabari shops) were visited to know about the saleable items coming from Hayatabad industrial estate on a daily basis.

Table 2: Solid waste composition at dumping site.

\begin{tabular}{ll}
\hline Type & Industrial Waste \\
\hline Recyclable/ Saleable & Plastic \\
Waste & Paper/cardboard \\
& Wood \\
& Rubber \\
& Metal/Iron scrap \\
& Glass and Ceramics \\
& Construction and demolition waste \\
Non-Recyclable & including sand, stones etc. \\
\hline
\end{tabular}

Solid waste collection efficiency

The collection efficiency of solid waste was calculated by Equation 1.

$$
E=C W / T W \times 100
$$

\section{Where;}

$\mathrm{E}$ is the collection efficiency of solid waste, $\mathrm{CW}$ is the total industrial waste collected and TW is the total waste generated. TW was calculated by investigating industries for their waste production. While CW was measured at the dumping site by quantifying solid waste carried by vehicles per day.

\section{Results and Discussion}

\section{Industries at hayatabad industrial estate}

According to secondary data collected from Sarhad Development Authority, the current installed industries at Hayatabad Industrial Estate are 372. Only 242 industries are functional while 58 are closed and 72 units are under construction. The plastic and pharmaceutical industries are large in number with 59 and 53 industrial units respectively. It was followed by marble (28), furniture (27) and food (24) industries. Almost all pharmaceutical industries are working on formulation. Some pharmaceutical industries received medicines from foreign countries and repacked them into the desired packing. Therefore, no outdoor pollution was expected. Similarly, plastic industries are also based on imported raw-materials and reshape it into different plastic products. Some indoor pollution was observed in the form of fumes, vapors and no complaints from the surrounding areas.

The marble industry is a small scale industry. Before 2010, they were observing 2 to 3 shifts per day of 8 hours each. During the study period (2014-18) the number of shifts has been decreased to one shift with 8 to 12 working hours per day. It has decreased the production rate of industries by $30-40 \%$. Other reasons of the decrease in duty hours and low production are the non-availability of raw material and skilled labor. The marble processing industry is a resource-intensive and is a regular source of pollution.

The furniture industry is a wood-based industry which needs a specific type of tree species (Poplar, Mulberry, Shesham etc.). They also observed one shift per day of eight to 12 working hours. These are pollution-causing industries; generate wood dust and wood-waste. The wood-waste is re-used as fuel. Food industries are 24 in number which can cause indoor pollution only. These industries are working below their capacity and observed a single shift only. Due to financial problems, the number of food industries has been dropped from 24 to 20 (Table 3).

Only 56 industries fall in 10 different categories (match, steel, chipboard, paper, fiberglass, ghee, ceramic, beverages, tire and packaging) are observing three shifts per day of eight hours each. These industries need continuous feed and are important from the environmental point of view. The remaining industries, categorized as "other", are 61 out of 
which 40 were functional (Table 3 ). These include engineering works, flour mills, cable industries etc. These generate waste which is re-used or sold.

\section{Solid waste produced at Hayatabad industrial estate}

The quantity of industrial solid waste was determined for functional industries of each type, given in Table 4. In industrial waste, greater contribution of solid waste was calculated for wood-based industries such as match $(42630 \mathrm{Kg})$, furniture $(2040 \mathrm{Kg})$, chipboard $(3093 \mathrm{Kg})$, paper-mill $(5412 \mathrm{Kg})$ and mold industries $(3120 \mathrm{Kg})$ per day. They produce solid waste in the form of wood and paper. The waste is not utilized properly which is an environmental concern. Marble industries also contribute a big part in solid waste production with $12481 \mathrm{Kg} /$ day. This waste is in the form of marble sludge and damaged marbles. The waste is not managed properly and is disposed of in nearby areas. Solid waste of carpet and woolen industries is varied depends upon its production capacity, clear weather and availability of raw material. The remaining industries also contributed a big part in industrial solid waste with $7728 \mathrm{Kg} /$ day (Table 4). This waste consists of different items depending upon the nature of industry. By analyzing the dumpsite and investigation from industries, solid waste generated at Hayatabad industrial estate is $125,481 \mathrm{Kg} /$ day.
Solid waste collection and disposal

The collection rate of total solid waste is $26,039 \mathrm{Kg}$ per day. The collected waste is transferred to landfill for disposal. Data analysis showed that $41 \%$ of industrial waste $(52,077 \mathrm{Kg})$ is thrown by industries on daily basis. About 33\% of solid waste consisted of recyclable items (plastic, iron scrap, paper and wood) is reused/recycled and the rest of $26 \%(32,577 \mathrm{Kg})$ waste is sold to the community as a fuel source on daily basis (Figure 2).

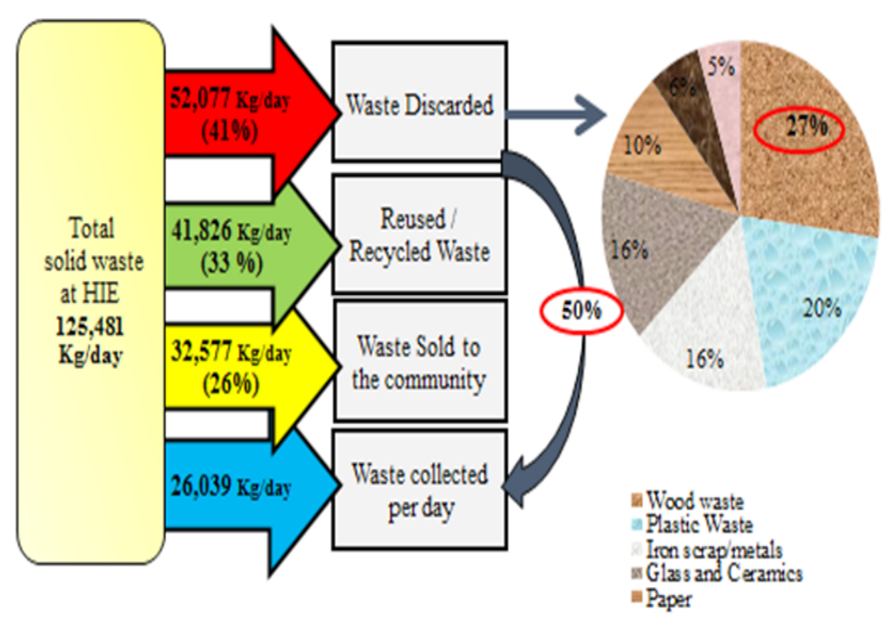

Figure 2: Solid waste collection, disposal and composition model of HIE, Peshawar.

Table 3: Major groups of industries in Hayatabad industrial estate.

\begin{tabular}{lllllll}
\hline S. No. & Industry & Number & Functional & Shifts & Working time (hour) & Production/Industry/day (tons) \\
\hline 1 & Pharmaceutical & 53 & 47 & 1 & $08-12$ & $5-6$ \\
2 & Plastic and PVC & 59 & 40 & 1 & $08-12$ & $12-15$ \\
3 & Marble & 28 & 23 & 3 & $08-12$ & $40-50$ \\
4 & Furniture & 27 & 14 & 1 & $08-12$ & Varies \\
5 & Food & 24 & 20 & 1 & $05-06$ & $3-4$ \\
6 & Match & 17 & 15 & 3 & 24 & $10-12$ \\
7 & Mold & 3 & 2 & 3 & 24 & $08-09$ \\
8 & Beverages/ Juices & 8 & 5 & 3 & 24 & 13 \\
9 & Chipboard/ Formica & 7 & 6 & 3 & 24 & $25-30$ \\
10 & Iron and Steel & 7 & 6 & 3 & 24 & 50 \\
11 & Aluminum & 6 & 3 & 1 & $05-06$ & $10-12$ \\
12 & Carpet/ woolen & 5 & 3 & 1 & $05-06$ & Varies \\
13 & Adhesive tape & 5 & 3 & 1 & $05-06$ & $2-3$ \\
14 & Oil and Ghee & 4 & 3 & 3 & 24 & $70-80$ \\
15 & Ceramic & 3 & 2 & 3 & 24 & 25 \\
16 & Fiber Glass & 3 & 4 & 3 & 24 & 30 \\
17 & Paper & 2 & 2 & 3 & 24 & $13-15$ \\
18 & Tire & 2 & 2 & 3 & 24 & 18 \\
19 & Paint & 2 & 2 & 1 & $05-06$ & $6-7$ \\
20 & Others & 61 & 40 & - & - & \\
21 & Total & 372 & 242 & - & - & - \\
\hline
\end{tabular}

Source: SDA Peshawar, 2018. 
Table 4: Solid waste produced by industries at Hayatabad industrial estate.

\begin{tabular}{|c|c|c|c|c|c|c|c|c|}
\hline \multirow{2}{*}{$\begin{array}{l}\text { S. } \\
\text { No. }\end{array}$} & \multirow[t]{2}{*}{ Industry } & \multirow{2}{*}{$\begin{array}{l}\text { Industries } \\
\text { surveyed }\end{array}$} & \multirow{2}{*}{$\begin{array}{l}\text { Questionnaire } \\
\text { received }\end{array}$} & \multicolumn{4}{|c|}{ Solid waste generated/industry } & \multirow{2}{*}{$\begin{array}{l}\text { Waste production / } \\
\text { day }(\mathrm{Kg})\end{array}$} \\
\hline & & & & Min & Max & Avg & S.D & \\
\hline 1 & Pharmaceutical & 12 & 7 & 43 & 50 & 46.31 & 1.21 & 2177 \\
\hline 2 & Plastic and PVC & 10 & 9 & 255 & 270 & 262.5 & 2.13 & 10605 \\
\hline 3 & Marble & 05 & 4 & 530 & 554 & 542.65 & 6.12 & 12481 \\
\hline 4 & Furniture & 06 & 6 & 135 & 152 & 146 & 1.19 & 2040 \\
\hline 5 & Food & 08 & 6 & 87 & 100 & 93.5 & 1.62 & 1970 \\
\hline 6 & Match & 07 & 5 & 2788 & 2860 & 2842 & 7.56 & 42630 \\
\hline 7 & Mold & 03 & 3 & 1490 & 1624 & 1557 & 8.11 & 3120 \\
\hline 8 & Chipboard & 03 & 3 & 472 & 554 & 513 & 5.15 & 3093 \\
\hline 9 & Iron and Steel & 05 & 4 & 325 & 374 & 350 & 3.14 & 2102 \\
\hline 10 & Aluminum & 04 & 3 & 160 & 200 & 180 & 2.22 & 541 \\
\hline 11 & Oil and Ghee & 03 & 3 & 90 & 120 & 105 & 1.23 & 316 \\
\hline 12 & Ceramic & 03 & 3 & 410 & 500 & 453.5 & 6.11 & 907 \\
\hline 13 & Fiber Glass & 03 & 3 & 145 & 190 & 170 & 2.32 & 510 \\
\hline 14 & Paper & 03 & 3 & 2600 & 2800 & 2706 & 7.44 & 5412 \\
\hline 15 & Paint & 02 & 2 & 40 & 60 & 54 & 1.03 & 108 \\
\hline 16 & Tire & 02 & 2 & 270 & 290 & 300 & 1.42 & 600 \\
\hline 17 & Carpet/woolen & 02 & 2 & 150 & 245 & 200 & 1.11 & 600 \\
\hline 18 & Beverages & 02 & 2 & 90 & 120 & 100 & 1.12 & 500 \\
\hline 19 & Adhesive Tape & 02 & 2 & 50 & 80 & 67 & 1.01 & 200 \\
\hline 20 & Others & 10 & 8 & 150 & 218 & 193 & 1.02 & 7728 \\
\hline 21 & Total & 95 & 80 & - & - & - & - & 125,481 \\
\hline
\end{tabular}

Solid waste of the Hayatabad area is collected through trucks, tractor and trolleys and donkey carts. The number of registered vehicles hired by PDA for solid waste collection is 95 carts, 6 tractors/trolleys and 3 trucks. These vehicles are used to collect solid waste from residential and industrial areas in mixed form. The capacity of cart, trolley and truck is 300 $\mathrm{Kg}, 3612 \mathrm{Kg}$ and $4535 \mathrm{Kg}$ respectively. Vehicles collect solid waste and transfer it to landfill with a charge of 300/-cart and 1500/-tractor or truck per day. In addition to these sources, some unregistered carts have also been used to collect solid waste on a voluntary basis. Unregistered carts collect a selective type of solid waste that is salable in the market. The carts of volunteers visit selected places, rich in valuables. The solid waste landfill site is located in Hayatabad near Phase-7. Donkey carts, tractors and trucks bring the collected waste to this site. Much of the waste is dumped illegally in nearby areas that are not designated for this purpose. In addition, some recyclable waste is burned or dumped openly. The majority of industries use their own services for the transport of solid waste to the landfill site. No separate landfill or treatment facility is available for industrial waste. Therefore, the management of industrial waste is one of the main environmental problems of the industrial zone of Hayatabad. Respondents (owners/ managers of industries) of industries complained that the collection of industrial waste is not regular and is usually burned in open areas. Part of the recyclable waste, including cans, bottles, wood and cardboard, is collected by garbage collectors/scavenger. The role of scavenger can have a significant impact on the industrial economy and waste management.

\section{Solid waste composition}

The industrial waste consisted of recyclable/saleable items such as wood-waste (27\%), plastics (20\%), glass and ceramics (16\%), iron scrap/metals (16\%), paper (10\%) and rubbers (6\%). The non-recyclable waste was observed as $5 \%$ (sand, stones etc.) as shown in Figure 2. Some paper and plastic shoppers, degraded or damaged cannot be recycled.

\section{Solid waste at scrap collection shops}

The quantity of waste collected from the dumping site and industries consisted of items such as paper, plastic, glass bottles, wood, and iron scrap. These 
items are collected by scavengers and then sold to scrap collection shops (kabari shops). There are more than 30 scrap collection shops located outside the industrial estate. The shops buy salable items with different rates according to item type (Table 5).

\section{Solid waste collection efficiency}

Based on the composition of industrial waste, the recovery efficiency for paper/cardboard, plastics, rubber, glass bottles, iron scrap and wood was calculated as $4 \%, 2 \%, 0.3 \%, 0.2 \%, 1 \%$ and $3 \%$ respectively (Table 5). The collection efficiency for total industrial solid waste was $50 \%$. About half of disposed waste is collected while the remaining part is dumped openly or thrown near the roadside which is one of the major environmental problems.

Compared to solid waste collection in other parts of Pakistan, the situation was almost similar. In Pakistan, industrial waste is usually dumped in open dumps and untreated. The situation was worse for Sindh Industrial Trading Estate (SITE) and Landhi Industrial Trading Estate, Karachi (LITE). These industrial areas generate a huge amount of solid waste which is not handled or treated properly. This mismanagement leads to serious risks for the environment (Khalid et al., 2017; Javed and Hayat, 1998).

The literature has revealed that in European countries (Spain,Poland,etc.),solid waste management practices are not effective due to the lack of implementation of government laws (Grodzinska-Jurczak, 2001). In Lebanon, the recyclable elements of industrial waste are generally discarded. Due to the poor management of industrial waste, the industrial share is only $17 \%$ in the economy (El-Fadel et al., 2001). In Taiwan, industrial solid waste is properly treated under the supervision of the Taiwan Environmental Protection Agency. The reuse and recycling process is very efficient with a record recycling of 1.97 million metric tonnes (Wei et al., 2001). In China, a gradual development of industrialization has increased the amount of production of industrial solid waste, hence the low rate of waste disposal and use. The study reported that industrial solid waste increased to 3.25 billion tonnes (Wen et al., 2014). Today, China has improved the management of industrial solid waste, which has significantly reduced the rate of waste discharge and increased its use to $11.5 \%$ (Chen et al., 2014).

Table 5: Composition and collection efficiency of industrial solid waste.

\begin{tabular}{lllllll}
\hline S. No. & $\begin{array}{l}\text { Composition of solid } \\
\text { waste }\end{array}$ & $\begin{array}{l}\text { Quantity of solid } \\
\text { waste (Kg/day) }\end{array}$ & $\begin{array}{l}\text { Total weight sold to 30 } \\
\text { shops (Kg/day) }\end{array}$ & Rs/Kg & $\begin{array}{l}\text { US Dol- } \\
\text { lar }\end{array}$ & $\begin{array}{l}\text { Recovery } \\
\text { efficiency (\%) }\end{array}$ \\
\hline 1 & Paper/cardboard & 150 & 4,500 & $15 /-$ & 0.13 & 4 \\
2 & Plastics & 70 & 2,100 & $20 /-$ & 0.18 & 2 \\
3 & Rubber & 10 & 300 & $05 /-$ & 0.05 & 0.3 \\
4 & Glass bottles & 8 & 240 & $05 /-$ & 0.05 & 0.2 \\
5 & Iron scrap/metals & 48 & 1,440 & $30 /-$ & 0.27 & 1 \\
6 & Wood & 120 & 3,600 & $05 /-$ & 0.05 & 3 \\
\hline
\end{tabular}

Table 6: Perception of industrial industrialists about solid waste management.

\begin{tabular}{lllll}
\hline S. No. & Type of Activity & Satisfactory \% & Poor \% & Good \% \\
\hline 1 & Solid waste collection from industries & 22.5 & 67.5 & 10.0 \\
2 & Solid waste recycling by industries & 37.5 & 42.5 & 20.0 \\
3 & Energy/power generation from Solid waste & 10.0 & 85.0 & 5.0 \\
4 & Safe storage of Solid waste & 32.5 & 47.5 & 17.5 \\
5 & Disposal of solid waste & 27.5 & 57.5 & 15.0 \\
6 & Treatment of solid waste & 15.0 & 82.5 & 2.5 \\
7 & Volume of Solid waste reduced by industry & 32.5 & 62.5 & 10.0 \\
8 & Industrial Symbiosis as treatment approach & 12.5 & 77.5 & 10.0 \\
9 & Economics of solid waste management & 22.5 & 62.5 & 16.0 \\
10 & Transportation problems & 35.0 & 40.0 & 25.0 \\
11 & Water pollution & 25.0 & 57.5 & 17.5 \\
12 & Concern about health and safety & 27.5 & 60.0 & 12.5 \\
13 & Role of EPA & 20.0 & 72.5 & 7.5 \\
\hline \hline June 2021 & Volume 40 | Issue 1 | Page 65 & & \\
\hline
\end{tabular}


Waste minimization and its management

Waste management plays an important role in reducing environmental pollution. In this part, industries are responsible for managing waste generation, reuse, recycling and reduction (Rehman et al., 2012). Table 6 summarizes the solid waste data collected through a questionnaire from industries. The responses were recorded under three categories, namely satisfactory, good and bad. The efficiency of solid waste collection was rated $10 \%$ good, $22.5 \%$ satisfactory and $67.5 \%$ poor. Recycling of solid waste was rated $20 \%$ good and $42.5 \%$ bad. While the safe storage of solid waste was $17.5 \%$ good. To protect the environment and control pollution, the responsible authorities in Pakistan are the Pakistan Environmental Protection Council (PEPC) and the Pakistan Environmental Protection Agency (PEPA) (UNIDO, 2000). In 2014, the Khyber Pakhtunkhwa Environmental Protection Law was approved by the provincial EPA to protect the environment. The performance of the environmental protection agency, Peshawar, was rated as poor. On top of that, no checks and balances on industries were noticed. With the efforts of the PEPA, the industrial sector is now aware of environmental management and clean technologies, but there is a need to implement the rules. Likewise, cooperation and decision-making between government agencies is still fragmented (Khalid et al., 2017; Khan et al., 2008).

Advanced and creative approaches can be useful for solid waste management, and environmental degradation issues have been solved in some cases (Devlin et al.,2017). For the management of industrial waste, the encouragement of industrial symbiosis has been considered a good practice which absorbs energy and materials and converts them into useful products (Alhumoud et al., 2008). This approach is the mutual relationship of industries where one industry feeds on the waste resources of another industry and then transfers or recycles that waste into by-products (Puente et al., 2015). Industrialists found themselves oblivious to the concept of industrial symbiosis. There is no such facility for using industrial waste. The implementation and supervision of industrial waste management was observed to be negligible. Energy production from solid waste was also low. Waste like paper, wood, scrap metal is reused by industries, but the majority of industries prefer to sell these types of waste to local people for combustion. The efficiency of solid waste minimization was good at
$10 \%$. The problems of transport and water pollution were counted unsatisfactory $40 \%$ and $57.5 \%$. These problems relate to inappropriate waste disposal and landfill in open areas. Such conditions create unhygienic environmental problems.

The waste disposal method was rated $15 \%$ good. According to the statement of the industrialists, the government demanded to provide us with advanced technology. In addition, the solid waste treatment rate was poor with a score of $82.5 \%$. This has a negative impact on the health of workers (Table 6). Therefore, solid waste management is a big problem to deal with. Various waste management issues were identified during field surveys, such as collection, transport and disposal. Much of the solid waste, including recyclable waste, is burned or dumped in neighboring areas which are a major cause of environmental pollution nearby. Several incidents were recorded in the industrial zone of Korangi Karachi due to the inappropriate dumping of hazardous industrial waste (Jabeen et al., 2015). The negligible industry response to solid waste management is due to its poor performance, lack of up-to-date technologies and experts (Geyer et al., 2016). With the introduction of new technologies and waste minimization approaches, it is considered important to reduce industrial waste to the lowest level (Laurent et al., 2014; Khan et al., 2018).

\section{Conclusions and Recommendations}

There is no separate collection system for the industrial waste. Industrial solid waste is mixed with municipal solid waste. This mechanism of waste collection and disposal is a major problem. There was no arrangement for recovery from solid waste at the collection and disposal site. No weighing facilities were noticed for industrial and residential waste. There is potential for recycling which is overlooked. Open burning of waste including plastic and rubber causes air pollution which is the most common practice. The overall observation showed a limited focus on the control mechanism of industrial waste management. Due to the lack of treatment facilities, landfills and recycling systems for industrial solid waste, people face an unhygienic environment. This mismanagement of solid waste paves the way for environmental pollution, leading to adverse effects on the environment and humans. The marble industries generate complex wastes in the form of wastewater and marble slurry. The existing mechanism in the marble units was inefficient in 
terms of recovering the marble slurry. Majority of industries generate waste which need to be utilized by other industries as their raw material. By utilizing the waste as raw material needs implementation of strong and effective policies.

Following recommendations are suggested to improve the waste management of industries as:

- There is an urgent need to arrange and manage separate solid waste collection and disposal facilities for Hayatabad Industrial Estate.

- A mechanism must be developed to initiate segregation and recovery at the source.

- Marble waste is a good raw material in the preparation of secondary products. Marble waste is a rich source of $\mathrm{CaCO}_{3}$ and is a good raw material in washing surf, cement and title industries. By using it as a raw material, this will help protect the environment and would be cost-effective [27].

- There is need to find ways for treatment (recycling or reuse) and avoid the wastage of recyclable solid waste such as wood-waste, paper-waste, plastic, iron scrap etc.

- The industrial sector should be based on publicprivate partnership; therefore government should regulate and encourage the private sector by enforcing the regulations for waste collection.

- The most appropriate method to reduce the pollution is based on recycling of waste. This will help in savings in economy, energy, resources and will reduce the waste production in sustainable way.

\section{Acknowledgments}

Authors are thankful to the nice staff of Sarhad Development Authority, Peshawar Development Authority and honorable managers and Plants incharge of visited industries for their assistance in providing relevant data. Shopkeepers of scrap collection shops are highly acknowledged for their co-operation in this study.

\section{Novelty Statement}

Industrial waste contains many important elements which can be reused and recycled. This helped to know the importance of many salable items as waste with the aim of reducing costs, saving energy and resources with concepts of sustainability and green economy.

\section{Author's Contribution}

Nazish Huma Khan: Conducted the research as part of her PhD work.

Mohammad Nafees: Supervised the research.

Tooba Saeed and Adila Bashir: Performed field survey.

Khaliq Ur Rahman: Analysed the data.

\section{Conflict of interest}

The authors have declared no conflict of interest.

\section{References}

Alhumoud, J.M. and F.A. Al-Kandari. 2008. Analysis and overview of industrial solid waste management in Kuwait. Manage. Environ. Qual. Int. J., 19(5): 1477-7835. https://doi. org/10.1108/14777830810894210

Arushanyan, Y., A. Bjorklund, O. Eriksson, G. Finnveden, S.M. Ljunggren, J.Q. Sundqvist and A. Stenmarck. 2017. Environmental assessment of possible future waste management scenarios. Energies, 10: 247-273. https://doi.org/10.3390/ en10020247

Bhat, S.A., S. Sharanpreet, S. Jaswinder and K.B. Sunil. 2018. Review on bioremediation and detoxification of industrial wastes by earthworms: Vermicompost as powerful crop nutrient in sustainable agriculture. Bioresour. Technol., 252: 172-179.

Chen, X., J. Pang, Z. Zhang a https://doi. org/10.1016/j.biortech.2018.01.003 nd H. Li. 2014. Sustainability assessment of solid waste management in China: A decoupling and decomposition analysis. Sustainability, 6(12): 9268-9281.https://doi.org/10.3390/su6129268

Devlin, F.D., 2017. Explaining industrial symbiosis emergence, development and disruption: A multilevel analytical framework, 21(1): 6-15. https://doi.org/10.1111/jiec.12398

El-Fadel, M., M. Zeinati, K. El-Jisr and D. Jamali. 2001. Industrial waste management in developing countries: The case of Lebanon. J. Environ. Manage., 61(4): 281-300. https://doi. org/10.1006/jema.2000.0413

Ewijk, S.V., A. Julia, Stegemann and E. Paul. 2018. Global life cycle paper flows, recycling metrics, and material efficiency. J. Ind. Ecol., 22(4): 686693. https://doi.org/10.1111/jiec.12613

Fan,J.C.,X.X.Zhou,L.J.Jianzhong and K.C.Zhou. 
2017. Comparison of the catalytic effects of eight industrial wastes rich in $\mathrm{Na}, \mathrm{Fe}, \mathrm{Ca}$ and $\mathrm{Al}$ on anthracite coal combustion. Fuel, 187(1): 398402. https://doi.org/10.1016/j.fuel.2016.09.083

Geyer, R., B. Kuczenski, T. Zink and A. Henderson. 2016. Common misconceptions about recycling. J. Ind. Ecol., 20(5): 1010-1017. https://doi. org/10.1111/jiec. 12355

Grodzinska-Jurczak, M., 2001. Management of industrial and municipal solid wastes in Poland. Resour. Conserv. Recycl., 32(2): 85-103. https:// doi.org/10.1016/S0921-3449(00)00097-5

Haupt, M., M. Zschokke. 2017. How can LCA support the circular economy? $63^{\text {rd }}$ discussion forum on life cycle assessment, Zurich, Switzerland. Int. J. Life Cycle Assess., 22: 832-837. https://doi.org/10.1007/s11367-0171267-1

Homan, M., E. Bazrafshan and F. KordMostafapour. 2014. Qualitative and quantitative analysis of industrial zomne waste products (case study merjaveh industrial zone- zahedan). Int. Res. J. App. Basic Sci., 8(1): 576-583.

Jabeen, A., H. Xisheng and A. Muhammad. 2015. The challenges of water pollution, threat to public health, flaws of water laws and policies in Pakistan. J. Water Resour. Prot., 7(17): 1516-1526. https://doi.org/10.4236/ jwarp.2015.717125

Kanchana, S., R. Kathiravan, R.M. Jenifer, K. Priyanka and D. Neetha. 2014. Industrial solid waste management practices in medium and small scale industries located in Tamil Nadu. Int. J. Emerg. Technol. Adv. Eng., 4(6): 762767.

Khalid, F., M. Wasim and M.T. Qadri. 2017. Environmental impact of industrial effluent and contributions of managing bodies in context of Karachi. J. Inf. Commun. Technol., 11(1): 6375.

Khan, N.H., M. Nafees, T. Saeed, A. Khan and A. Bashir. 2018. Industrial symbiosis and industrial waste management in Wood-based industries. J. Ind. Pollut. Contr., 34(2): 2152-2158.

Laurent, A., J. Clavreul, A. Bernstad, I. Bakas, M. Niero, E. Gentil, T.H. Christensen and M.Z. Hauschild. 2014. Review of LCA studies of solid waste management systems-Part II:
Methodological guidance for a better practice. Waste Manage., 34(3): 589-606. https://doi. org/10.1016/j.wasman.2013.12.004

Ljunggren, S.M., O. Eriksson, A. Bjorklund, G. Ostblom, T. Ekvall, G. Finnveden, Y. Arushanya and J.O. Sundqvist. 2016. Integrated economic and environmental assessment of waste policy instruments. Sustainability, 8(5): 411-462. https://doi.org/10.3390/su8050411

Mahar, A., R.N. Malik, A. Qadir, T. Ahmed, Z. Khan and M.A. Khan. 2007. Review and analysis of current solid waste management situation in urban areas of Pakistan. Proc. Int. Conf. Sustain. Solid Waste Manage., Chennai, India, 41: 34-41.

Nisar, H., N. Ejaz, Z. Naushad and Z. Ali. 2008. Impacts of solid waste management in Pakistan: a case study of Rawalpindi city. Trans. Ecol. Environ., 109: 685-691. https://doi. org/10.2495/WM080701

Puente, R.M.C., E.R. Arozamena and S. Evans. 2015. Industrial symbiosis opportunities for small and medium sized enterprises: Preliminary study in the Besaya region (Cantabria, Northern Spain).J. Clean. Prod., 87: 357-374. https://doi. org/10.1016/j.jclepro.2014.10.046

Rehman, O., S.J.H. Kazmi and A. Alam. 2012. Mismanagement of solid waste and its impact on the environment of Peshawar city. Int. J. Learn. Dev., 2(4): 182-188. https://doi.org/10.5296/ ijld.v2i4.2213

Shah, S.H., 2014. Industrial solid waste management practices in Pakistan. J. Environ. Sci. Toxicol. Food Technol., 8(9): 88-95. https://doi. org/10.9790/2402-08938895

UNIDO, 2000. Industrial Policy and Environment in Pakistan. Prepared by Ministry of Environment, UNDP and UNIDO.

Wei, M.S. and K.H. Huang. 2001. Recycling and reuse of industrial wastes in Taiwan. Waste Manage.,21(1):93-97.https://doi.org/10.1016/ S0956-053X(00)00073-8

Wen, Q. S. Pan and L. Hu. 2014. Industrial solid waste treatment in China. Eng. Aust., pp. 1088.

Yasar, A., A. Fawad, A. Fateha, I. Amna and R. Zainab. 2010. Ravi River potentials, pollution and solutions: an overview. World Environ., 39, 39-40. 